\title{
Model State Law for Street and Highway Lighting
}

\author{
A. D. Cameron
}

It is necessary for a state to enact a suitable law in order that its subdivisions may be permitted to contract for public lighting. There has always been some provision in the laws of all states permitting the ordinary type of street lighting. There was no provision for special lighting such as Whiteways. Recently a number of States have amended the original law to provide for this new condition. Within the last year the same necessity has arisen with respect to Highway lighting.

There are still a great many states who have not passed laws covering Whiteway lighting, and with one or two exception, none of the states have passed law covering Highway lighting. In the states where such legislation exists, there is no particular uniformity in the laws; and provision is not always made to cover all possible conditions.

We have secured a collection of all such existing laws, and the Legal Department has prepared from them a model law covering every class and condition of public lighting, and embodying all the good points of previous legislation. There is no question but that each state could profitably annul their old acts and replace them by this new law. I hope you will find it possible to bring this attached form to the attention of the proper people in cach state.

\section{Street Lighting Improvement Lavs}

\section{TOWN :}

\section{ARTICLE I.}

Sec. 1 (260). Establishment of Lighting District. It shall be lawful for the town board of any town in this state to contract for the lighting of the strects, avenues, highways, public places and public buildings therein, outside of the corporate limits of any incorporated village in said town, upon such terms and for such time or period, not exceeding ten years, as the town board may deem proper or expedient, and to provide for the payment of the expenses thereof and may to establish one or more lamp or lighting districts therein. It shall be lawful for the town boards of two or more adjoining towns in this state, whenever a position for the establishment of a lamp or lighting district shall cover territory lying in two or more such adjoining towns, in this state, to contract for the lighting of the streets, avenues, highways, public places and public buildings therein, outside of the corporate limits of any corporated village in said towns, 
upon such terms and for such time or period not exceeding ten years, as the town boards of two or more adjoining such towns in joint session assembled may deem proper or expedient and to provide for the payment of the expenses thereof.

Sec. 2 (261). Petition for Lighting. Where there is no lighting district already formed within the town, and the expense of the lighting provided for is to be assessed against the amount to be collected upon the taxable property of the whole town, no petition or establishment of district shall be necessary. When the expense of the lighting provided for is to be assessed against amount is to be collected upon the taxable property of a district or there is another lighting district or districts already formed within the town no such contract shall be made unless a petition for such lighting, signed by a majority of the taxpayers, of such lamp or lighting district as the same appear upon the last preceding assessment roll shall be filed with the town clerk of said town thirty days before the contract is made, but in the counties of Nassau, Rockland, Suffolk and Westchester no such contract shall be made unless the petition for such lighting is signed by a majority of the resident taxpayers in such lamp or lighting district, unless it be a renewal or extension of such a contract. In case such proposed lamp or lighting district lies in two or more adjoining towns, a petition signed by a majority of the taxpayers of such lighting district as the same appear upon the last preceding assessment roll of such town may be filed with the clerk of any such towns, and a copy of such petition and its signatures, certified to be such by the clerk of the town with whom the original petition is filed shall thereupon be filed with the town clerk of each other such town, and such petition shall not be deemed filed within this section until so filed with the clerk of each such town. A joint meeting of the town boards of such towns for the purpose of transacting any business of such joint lamp or lighting district shall be held at any time upon written request of the supervisor of any such town to the clerk of each such town. It shall be lawful, however, for the town board of each town, a part of which is included in a ioint lamp or lighting district so established, to transact all business thereof in separate session, except that the establishment of the district and the adoption of an initial contract for lighting shall be done in joint meeting as provided in section one two hundred and sixty. For the purposes of such joint action in separate session a majority vote at a meeting of each such town board, upon the same resolution, shall be necessary. The town clerk of each such town shall file a copy of such minutes of separate meetings as refer to such lighting district with the town clerk of each other town, a part of which is included in such joint lighting, district and the action of the several town boards shall thereupon become effective for such joint district. 
Sec. 3 (262) Notice of Presentation of Petition. The town board, or if such district shall lie in two or more adjoining towns, then the town boards of each such town, shall cause notice of the same to be published for one week in one or more of the newspapers published in such town or towns, or if no newspaper be published in such town or towns, then by posting said notice in at least six public and conspicuous places in said district, of the filing of said petition, and the time and place when the same will be acted upon by said town board, or if such lighting district lies in two or more said adjoining towns, then when the same will be acted upon at a joint meeting of the town boards of such towns, to be held in the territory where such district is to be created.

Sec. 4 (261-a) Consolidation of Lighting District. Two or more adjoining lighting districts in the same town may be combined in a single lighting district by a resolution of the town board of said town, and two or more adjoining lighting districts, lying wholly or partly in different towns, any one of which lies in two or more adjoining towns may be combined in a single lighting district by resolution of the town boards of such towns in joint session. In case the existing contracts for lighting different parts of such combined district are, by the terms thereof, to expire at different times, no renewal of any such contract shall ke for a period longer than the unexpired portion of the term of the other such contract, if there be but two, or in case there be more than two such contracts, for a period longer than the unexpired portion of that one of such contracts which have the longest time to run.

Sec. 5 (262-a). Extension of Lighting District. Any existing lighting district may be extended by resolution of the town board of the town in which such district is situated, or by resolution in joint session of the boards of the several towns in which such district is situated, so as to include therein any part of such town or towns, adjoining such district, upon the written petition of a majority of the taxpayers as the same shall appear upon the last preceding assessment roll, owners of real property to be included in such proposed extension, duly filed with the clerk of the town in which such district is situated; or if such district lies in two or more adjoining towns, with the clerk of any one of such towns. A lighting district may be repeatedly enlarged and extended in accordance with the provisions of this section. No contract for lighting such extension shall be made for a period of time longer than the unexpired portion of the term of the existing contract for lighting said district; or, in case there shall be at the time of such extension more than one existing contract for lighting said district, for a period longer than the unexpired portion of that one of such coritracts which has the longest time to run. 
Sec. 6. (263) Levy of Tax for Payment of the Amount of Contract. The amount of any contract that may be entered into pursuant to the provisions of this article shall be assessed, levied and collected upon the taxable property in said town or district in the same manner, at the same time, and by the same officers as the town taxes, charges or expenses of said town are now assessed, levied and collected, and the same shall be paid over by the supervisor to the corporation, company person or persons furnisining or supplying said light. If the town boards of two or more adjoining towns shall, in ioint session, establish a lamp or lighting district in two or more adjoining towns, they shall determine the relative proportion of the expense of such lighting which shall be borne by each of said towns, and the amount of such expense shall be assessed and levied on the taxable property in such lighting district in each of said towns, and collected in the same manner and at the same time, and by the same officers as the town taxes or charges or expenses of the town in which said district is located are now assessed, levied and collected, and such relative expense shall be paid over by the supervisor of each of said towns to the corporation, company, person or persons furnishing or supplying said light.

Sec. 7 (264) Lighting Contracts in Towns and Village. Whenever a lighting district has been established lying in one or more towns, a town board has established a lighting district in a town and, thereafter, a portion of one of said towns containing a part of said lighting district, shall have been included within the boundaries of an incorporated village, it shall be lawful for the town boards of said towns said town board and the board of trustees of said village, in joint session, without petition therefor, to jointly make, renew or extend a contract for the lighting of the whole of said village and the portion of said district not included in said village, for a period not to exceed five years. For the purpose of such joint action, in separate session a majority vote upon the same resolution at a meeting of each town board and village board, in separate session, shall be necessary. The town board of the town in which said village is located and the trustees of said village shall determine the relative proportion of the expense of lighting that portion of said district located in said town that shall be borne by such town and village if a town board and a village board of trustees in joint session shall make, renew or extend such a contract, they shall determine the relative proportion of the expense of such lighting which shall be borne by such town and such village respectively, and the amount of such expense to be borne by such town shall be assessed and levied on the taxable property in said lighting district in said town and collected in the same manner and at the same time by the same officers as town taxes, charges and expenses of such 
town in which a portion of said district is located are now assessed, levied and collected, and such relative expense shall be paid over by the supervisor of said town to the corporation, company, person of persons supplying or furnishing said light. The portion of the expense to be borne by said village, shall be assessed, levied and collected at the same time and in the same manner as other village charges, expenses and taxes are levied, assessed and collected and shall be paid in annual installments commencing with making, renewal or extension of said contract to the corporation, company, person or persons furnishing or supplying said light to the amount of the contract. The expense of such lighting in such village shall not, for each fiscal year, exceed three and one-half mills on every dollar of the taxable property of said village as appears on the last preceding assessment roll before the making, renewal or extension of such a contract, unless authorized by a village election.

Sec. 8. (265) Town Contracts for Lighting Improved Highway or Bridges. The town board of any town, without establishing a lamp or lighting district as provided by this article and without petition as required by section two two hundred and sixty-one, may contract for the lighting of such improved highways or such bridges in the town outside of villages and cities, as the board deems needed for the safety or convenience of the public. Such contract shall be upon such terms and for such time or period, not exceeding five years, as the board deems proper or expedient. The amount payable annually thereunder shall be a town charge and shall be paid from the surplus money of the town, or if such surplus be insufficient, the town board may course not exceeding one thouthand dollars in any year to be assessed, levied and collected for such purpose at the same time and in the same manner as other town charges. Lighting may be contracted for pursuant to this section in addition to lighting contracted for on account of a lighting district or districts within the town.

\section{ARTICLE II.}

\section{COUNTY}

Sec. 9 (345) Lighting of Public Highways or Bridges. The board of supervisors of any county, subject to the approval of the state commissioner of highways, may from time to time provide for lighting public highways, or portions thereof, or bridges, located in such county outside of cities and villages. The initial action of the board shall be in the form of a proposal for submition to the commissioner. The highways, or portions thereof, or bridges to be lighted, and the manner of lighting, shall be set forth in such proposal. Such proposal shall be embodied in a resolution. The lighting of one or 
more of such highways or portions thereof, or bridges may be proposed in a single resolution. The board may provide for such lighting if its proposal be so approved or, if modifications be suggested by the commissioner, may adopt such modifications and provide for such lighting in conformity therewith. The expense of installing, maintaining and caring for such lighting shall be a county charge, and the moneys therefor shall be provided and appropriated in the same manner as to other county expenses. For furnishing of light under this section may be provided for by contract or otherwise, but nothing herein shall be deemed to authorize the board to acquire, construct or establish a lighting plant for such purposes. The installation of lights, fixtures and connections shall be done under the supervision of the county superintendent of highways. The board may provide for the care of such lights in such manner as it may deem proper. The board may, in its discretion, at any time discontinue the lighting of any highway, or portion thereot, of bridge provided for under this section.

\section{ARTICLE III.}

\section{VILLAGES :}

Sec. 1 (89) Lighting Districts. The board of trustees of a village shall have the power, upon application by a petition in writing of a majority of the taxpayers, resident owners of taxable real property within the boundaries of a proposed lamp or lighting district as the same appear upon the last preceding completed assessment roll, to establish such special lighting district or districts for the proposed system of street lighting and from time to time alter or extend the same with full power to order such construction and installation and to enter into a contract for lighting in such district or districts so established or extended as said board may deem proper or expedient. Such petition shall contain a map of such district and a description of the same, and said district or districts or any extension thereof shall become established by the filing by the board of tsustees of a certificate in the office of the village clerk describing the bounds of such district or districts or any extention of the same. The amount of any contract that may be entered into for such special lighting district, pursuant to the provisions of this subdivision, when established upon the petition of the property owners, shall be apportioned by the board of trustees by ordinance between the owners within such district and the village at large; but in no event shall said owners be charged more than the per centum specified in the application, and said amounts so apportioned to the property owners shall be assessed, levied and collected in the same manner and by the same officers as the village taxes, charges or expenses for such village are now 
assessed, levied and collected. The board of trustees may, on its own motion, and shall upon the petition of twenty-five electors qualified to vote upon a proposition, cause to be submitted at the next regular or special village election a proposition for a special lighting district or districts or any extentions thereof are established pursuant to a proposition submitted at any village election, the amount of any contract entered into for such special lighting shall be assessed, levied and between all of the taxable property in said village in the same manner and by the same officers as the village taxes, charges or expenses are now assessed, levied and collected.

Sec. 3. Board of Light Commissioners. A village, by adopting a proposition therefor at an annual election, may establish a board of light commissioners. The members of such board shall consist of three members and shall be appointed by the board of trustees for the terms of one, two and three years, respectively, and shall have all the powers and be subject to all the duties and responsibilities of such board of trustees as specified in the next eight sections.

Sec. 3 (240). Contracts for Lighting. The board of trustees, light commissioners, may contract, in the name of the village, with an individual or corporation, for lighting the streets, public grounds and public buildings of the village by gas, electricity or other substance; but such contract shall not be made for a longer period than ten years, nor at an expense for each fiscal year exceeding five mills on every dollar of taxable property of the village as appears on the last preceding village assessment-roll, unless authorized at a village election. The amount of such contract shall be paid in installments, commencing with the date of the contact.

Sec. 4 (241). Election for Lighting System. A proposition may be submited at a village election for the establishment of a system for supplying the village and its inhabitants with light by any approved method, or for the acquisition of an existing private system, at an expense in either case not exceeding the sum stated in the proposition.

Sec. 5 (242). Acquisition of Existing Private System. If a proposition be adopted for the acquisition of an existing private lighting system, the board of trustees, light commissioners, may purchase the same at a prince not exceeding the sum specified therein. If the board can not agree with the owners of the system for its purchase, proceedings may be taken to aquire the, same by condemnation. If the value thereof fixed by the commissioners appointed, in the condemnation proceedings be greater than the sum specified in the proposition, such proceedings must be discontinued, unless the payment 
of the additional amount be authorized at a village clection. If the proceedings be so discontinued, the costs and disbursements of the defendants therein are a charge against the village.

Sec. 6 (243). Establishment of Lighting System. If a proposition to establish a lighting system be adopted, the board of tsustees shall proceed to construct such system accordingly. It shall prepare a map and plans of such system, indicating the streets and localities in the village to be supplied with light thereby, and shall file the same in the office of the village clerk. The board of trustees, light commissioners, may acquire in the name of the village, by purchase, if it can agree with the owners, or otherwise by condemnation, any land necessary for such system. The board may amend the map and plans at any time and such amended map shall be filed in the office of the village clerk in like manner as the original. The board may construct such lighting system by contract or otherwise.

Sec. 7 (244). Supervision and Extension of System. The lighting system acquired or established under this article shall be under the control and supervision of the board of trustees, light commissioners. The board shall keep it in repair and shall have authority to purchase such supplies and materials as may be needed for the operation and maintenance of such system for periods not exceeding one year. Such board may, from time to time, if it has sufficient funds, extend such system, if the estimated expense of such extention will not involve the issuance of bonds or certificates of indebtedness. If the estimated expense is greater than the amount of moneys available, such extension can only be made when authorized by a proposition, adopted at an election, in which event, it shall be so made. Such system may be so extended outside the village in, upon and along the highways within a town in which the village is wholly or partly situated, or within a town adjoining that in which the village is situated if the village be wholly within one town and in a county of less than one hundred thousand population provided however, that if at the time of such extension there shall be a private electric light corporation operating within such village or within the territory into which such system shall be extended, such extension shall not be made without the permission and approval of the proper public service commission. If such system shall be so extended outside of a village into or through a town or adjoining town or a lighting district thereof, the board of trustees, light commissioners, of the village may contract with the town board of such town for lighting the streets, highways, public grounds and public buildngs of such town or lighting district, in pursuance of the provisions of article one, twelve of the town law, which shall be 
applicable to such contract and to the levying of a tax for the payment of the amounts which shall be payable thereunder to the treasurer of the village. Wherever such system shall be so extended outside a village, occupants of premises adjacent to such extended system outside the village shall be entitled to be supplied with light therefrom under the same conditions and at the same rates as occupants of premises in the village.

Sec. 8 (245) Ordinances. The board of trustees, light commissioners, may adopt ordinances, not inconsistent with law, for enforcing the collection of light rents and relating to the use of light, and may enforce observance thereto by cutting off the supply of light or by the imposition of penalties.

Sec. 9 (216) Establishment of Light Rents. The board of trustees, light commissioners, shall establish a scale of rents for the use of light, to be called "light rents", and to be paid at such times as the board may prescribe.

Sec. 10 (247) Annual Report of Trustees, Light Commissioners. Between the first and forth day of March in each year, the board of trustees, light commissioners, shall file with the village clerk a report containing a statement of the following facts :

1. The amount of money on hand at the begining of the preceding fiscal year, and the receipts from all sources during such year.

2. An itemized statement of the amount paid out during such year, and the balance on hand.

3. The outstanding indebtedness of the department, either bonded or otherwise, separately stated.

4. The estimated deficiency in the amount necessary to pay the principal or interest or the expenses of the department during the next fiscal year, after applying thereto the probable amount of light rents to be received, and any amount available from the sinking fund.

5. The improvements and extensions made during such preceding year, and the general condition of the lighting system.

6. Such other facts as the board deems important for the information of the village, together with such recommendations concerning the department as may be deemed proper.

\section{ARTICLE IV.}

\section{CITIES :}

Sec. 2 (19) Municipal Lighting. Cities having population not exceeding. One Hundred Thouthand. Special Lighting District. The common council, in cities of the 
third class, or other governing body, in cities having a population not exceeding one hundred thouthand, shall have the power, upon application, in writing, of the property owners, owning at least two-thirds of the number of feet fronting or abutting upon the street and along the line of any proposed improvement for the construction of an improved system of street lighting, to establish such special lighting district or districts for the proposed system of strcet lighting, and from time to time may alter or extend the same, with full power to order such construction and installation and to enter into a contract for lighting in such district or districts so established or extended as they may deem proper or expedient.

The amount of any such contract that may be entered into for such special lighting, pursuant to the provisions of this act, shall be assessed, levied and collected upon and between the taxable property in said city and the district or districts respectively, in the same manner and by the same officers as city taxes, charges or expenses for said city are now assessed, levied and collected.

The common council shall, by ordinance, apportion the expenses that shall be borne by the property fronting upon the street and along the line of the proposed system or systems, and the city at large; but in no event shall the property fronting or abutting upon the street or streets along the line of the proposed system or systems be charged less than fifty per centum for such charges or expenses, nor more than the per centum specified in the application and agreed to by the property owners.

The common council, or other governing body, if the expense thereof is to be borne by the city at large, may contract for the lighting of such city with full power to order such installation and construction as may be necessary for such purpose. No contract provided for under this section shall be for a period exceeding five years.

Sec. 2 (122) Municipal Lighting-Cities having Population Exceeding One Hundred Thousand, Contracts for Lighting. All municipal lighting shall be supplied pursuant to contract therefor, awarded by the board of contract and supply as herein provided. Such contract shall cover and include the lighting and supplying of the lamps and the oil, gas, electric current, the cleaning, repair and renewal of the materials required in the use and care thereof. No bid or proposal for any such contract shall be received, nor contract awarded therefor, unless the bidder shall prior to the making of such bid or proposal, have a franchise under the authority of which the proposed contract can be performed. No contract shall be advertised for or entered into for a period exceeding five years. Each bidder shall be required to furnish with each bid or proposal a certified check, payable to the order of the city treasurer, in such sum as the board of 
contract and supply shall prescribe, but not less than ten thousand dollars. Such sum shall, be forfeited to and become the absolute property of the city in case the bidder depositing the same shall be awarded the contract and shall not execute the same and furnish a bond for the faithful performance of such contract, in the penal sum of not less than fifty thousand dollars, within thirty days after the award of such contract. Such certified check shall be returned to the bidder, if the contract be not awarded to him, or, if awarded, he shall have executed and contract and required bond.

The common council may by ordinance establish a special lighting district or districts for the purpose of ornamental street lighting, and from time to time may alter or extend the same. The board of contract and supply may contract for lighting any such district or districts so established or extended, as such board may deem proper or expendient. Any contract so entered into shall be in conformity with the provisions of this section, except that the bond to be given for the faithful performance of the contract shall be in such amount as the board of cuntract and supply shall determine. The amount of any contract that may be entered into for such special lighting pursuant to the provisions of this section, shall be assessed ratably upon the real property in such lighting district or districts in such manner as shall be provided by an ordinance duly adopted by the common council and approved by the board of estimate and apportionment; and such assessments shall be levied, enforced and collected upon and between the taxable property in said city and district or districts respectively, in the same manner, by the same proceedings at the same time, under the same penalties and by the same officers as the city taxes, charges or expenses of said city are now levied, enforced and collected. The common council shall, by ordinance, approved by the board of estimate and apportionment, apportion the expence that shall be borne by the taxable property in such special lighting district or districts, and the city at large; but in no event shall the taxable property in any such special lighting district or districts be charged with less than fifty per centum of such charges or expenses. 